\title{
PENGARUH KEPEMIMPINAN KEPALA SEKOLAH DAN KOMITMEN GURU TERHADAP PENERAPAN NILAI-NILAI HIDUP ISLAMI DI SMK MUHAMMADIYAH KABUPATEN TEGAL
}

\author{
Nurokhman \\ Program Pasca Sarjana Magister Studi Islam \\ Universitas Muhammadiyah Yogyakarta \\ E-mail: nurokhman_sag@yahoo.com
}

\begin{abstract}
Abstrak
Penelitian ini bertujuan untuk mengetahui: pengaruh kepemimpinan Kepala Sekolah, komitmen guru, dan pengaruh simultan kepemimpinan Kepala Sekolah dan komitmen guru terhadap penerapan nilai-nilai hidup Islami di SMK Muhammadiyah Kabupaten Tegal. Penelitian ini menggunakan pendekatan mixed method. Populasi penelitian ini adalah seluruh Kepala Sekolah, guru, dan siswa SMK Muhammadiyah se Kabupaten Tegal. Teknik sampling yang digunakan yaitu proportionate sampel stratified random sampling. Teknik pengumpulan data menggunakan kuesioner, wawancara, observasi, dan dokumentasi. Hasil penelitian menunjukkan bahwa: (1) kepemimpinan Kepala Sekolah berpengaruh signifikan terhadap penerapan nilai-nilai hidup Islami di SMK Muhammadiyah Kabupaten Tegal, nilai sig sebesar 0,013 < 0,05. nilai; (2) komitmen guru berpengaruh signifikan terhadap penerapan nilai-nilai hidup islami di SMK Muhammadiyah Kabupaten Tegal, nilai sig sebesar 0,006 <0,05; dan (3) Secara simultan kepemimpinan Kepala Sekolah dan komitmen guru berpengaruh signifikan terhadap penerapan nilai-nilai hidup islami di SMK Muhammadiyah Kabupaten Tegal, nilai sig sebesar $0,002<0,05$.
\end{abstract}

Kata kunci: kepemimpinan kepala sekolah, komitmen guru, penerapan nilai-nilai hidup islami.

\begin{abstract}
This study aims to determine: Principal leadership influence, teacher commitment, and simultaneous influence of principal leadership and teacher commitment to the implementation of Islamic life values at SMK Muhammadiyah Tegal regency. This research uses mixed method approach. The population of this research are all principals, teachers, and students of SMK Muhammadiyah se Kabupaten Tegal. The sampling technique used is proportionate sample stratified random sampling. Data collection techniques used questionnaires, interviews, observations, and documentation. The results showed that: (1) Principal leadership had a significant effect on the application of Islamic life values in SMK Muhammadiyah Kabupaten Tegal, sig value of $0.013<0.05$. value; (2) teacher commitment has significant effect on the implementation of Islamic life values at SMK Muhammadiyah Kabupaten Tegal, sig value equal to $0.006<0.05$; and (3) Simultaneously, Principal Leadership and teacher commitment have a significant effect on the implementation of Islamic life values in SMK Muhammadiyah Kabupaten Tegal, sig value of $0.002<0.05$.
\end{abstract}

Keywords: principal leadership, teacher commitment, implementation of Islamic life values.

\section{Info Artikel}

Diterima Januari 2018, disetujui Februari 2018, diterbitkan Juni 2018

Dipublikasikan Oleh: Program Studi Bimbingan dan Konseling 


\section{PENDAHULUAN}

Penerapan nilai-nilai Islami dalam kehidupan warga sekolah di Perguruan Muhammadiyah merupakan bagian yang tidak dapat dipisahkan dari tujuan penyelenggaraan pendidikan Muhammadiyah. Kesadaran akan pentingnya nilai, moral dan keagamaan serta pengembangan pengajaran yang memadukan keimanan dan ketaqwaan dalam pendidikan Muhammadiyah merupakan bagian tak terpisahkan dari tujuan pendidikan nasional;

"Pendidikan nasional bertujuan untuk berkembangnya potensi peserta didik agar menjadi manusia yang beriman dan bertaqwa kepada Tuhan Yang Maha Esa, berakhlaq mulia, sehat, berilmu, cakap, kreatif, mandiri dan menjadi warga negara yang demokratis serta bertanggung jawab”.

Kepemimpinan kepala sekolah yang efektif dan komitmen guru merupakan potensi utama dalam mewujudkan tujuan sekolah. Ian Alwyn Marshall dalam Journal of Arts \& Humanities "Principal leadership style and Teacher Commitment among a Sample of Secondary School Teachers in Barbados" menyampaikan bahwa kepemimpinan kepala sekolah merupakan inti dari permasalahan yang berdampak pada tingkat komitmen dan produktivitas umum antara guru, dan jika guru tidak berkomitmen maka akan ada implikasi serius terhadap kualitas pengajaran dan pembelajaran yang diberikan, serta berdampak buruk pada realisasi tujuan organisasi.

Berdasarkan kajian Ian Alwyn Marshall, dan fakta adanya beberapa kasus kriminal siswa di SMK Muhammadiyah Kabupaten Tegal, menunjukkan adanya indikasi lemahnya kepemimpinan Kepala Sekolah dan komitmen guru sekolah Muhammadiyah dalam upaya penerapan nilai-nilai hidup Islami pada siswa dalam aktivitas sehari-hari, baik dalam kegiatan kurikuler maupun ekstra kurikuler.

\section{LANDASAN TEORI}

\section{Kepemimpinan Kepala Sekolah}

Kepemimpinan merupakan faktor yang sangat penting dalam menentukan keberlangsungan sebuah organisasi. Kartono (2005), kepemimpinan adalah kemampuan untuk memberikan pengaruh yang konstruktif kepada orang lain untuk melakukan suatu usaha kooperatif mencapai tujuan yang sudah direncanakan.

Edmons (1979) menyatakan bahwa kepala sekolah adalah individu kunci dalam mengembangkan sekolah mereka. Keberhasilan sekolah dalam pencapaian tujuan sekolah sangat berkait dengan efektifitas kepemimpinan kepala sekolahnya. Donni Juni Priansa dan Rismi Somad dalam kajiannya tentang kepemimpinan kepala sekolah 
menjelaskan bahwa kepemimpinan kepala sekolah yang efektif adalah kepemimpinan yang mampu memberdayakan seluruh potensi yang ada di sekolah dengan optimal, sehingga guru, staf, dan siswa merasa ikut terlibat dalam pencapaian tujuan dan sasaran yang telah ditetapkan oleh sekolah. Kepemimpinan kepala sekolah yang efektif adalah kepemimpinan yang mampu memberikan kepuasan bagi stakeholders sekolah. Kepemimpinan kepala sekolah yang efektif adalah kepemimpinan yang mampu memberikan inspirasi dan teladan yang baik bagi guru, staf dan siswa.

\section{Komitmen Guru}

Keberhasilan proses belajar mengajar sangat tergantung kepada bagaimana guru melaksanakan tugasnya dalam mendidik, mengajar, membimbing, mengarahkan, melatih dan menilai peserta didik terlaksana dengan baik dan menyakinkan. Glatthorm (1990) mengemukakan bahwa dalam melaksanakan tugas profesi guru, disamping kemampuan dalam melaksanakan tugas, seorang guru juga harus mempertimbangkan aspek komitmen dan tanggung jawab serta kemandirian.

Komitmen menurut Glickman (1981) adalah kemauan kuat untuk melaksanakan tugas yang didasari dengan rasa penuh tanggung jawab. Lebih lanjut Glickman menggambarkan ciri-ciri komitmen guru profesional, antara lain: (1) tingginya perhatian terhadap siswasiswi; (2) banyaknya waktu dan tenaga yang dikeluarkan; dan (3) bekerja sebanyak-banyaknya untuk orang lain. Sedangkan Park mendefinisikan komitmen guru sebagai kekuatan batin yang datang dari dalam hati seorang guru, dan kekuatan dari luar itu sendiri tentang tugasnya yang dapat memberi pengaruh besar terhadap sikap guru berupa tanggung jawab dan responsiv terhadap perkembangan ilmu pengetahuan dan teknologi.

\section{Nilai-Nilai Hidup Islami di Sekolah}

Nilai-nilai hidup Islami adalah seperangkat nilai dan norma yang bersumber pada Alqur`an dan Sunnah yang menjadi pola tingkah laku dalam menjalani kehidupan sehari-hari. Nilai-nilai Agama Islam sebagai sebuah sistem pada akhirnya mewujud dalam perilaku, baik peorangan maupun organisasi, yang selanjutnya diinstitusikan. Institusional nilai yang terbaik dilakukan melaui upaya pendidikan; "Education in islam is not merely of Acquiring intellectual knowledge but is a mean of moulding the nature and character of an individual so that they can collectively represent Islamic values".

Pendidikan dalam islam bukan semata-mata untuk memperoleh pengetahuan intelektual, tetapi lebih dari itu sebagai sarana untuk mencetak sifat dan karakter seseorang sehingga mereka secara bersama-sama dapat menunjukkan nilai-nilai islam. Oleh karena itu, tanggung jawab utama 
lembaga pendidikaan islam untuk menanamkan nilai-nilai Islami dalam kehidupan sehari-hari di sekolah.

\section{METODOLOGI PENELITIAN}

Pendekatan yang digunakan dalam penelitian ini adalah mixed method dengan desain sequential expalantory. Penelitian ini merupakan jenis penelitian korelasional antar variabel yang bertujuan untuk mendeskripsikan dan menganalisis pengaruh kepemimpinan Kepala Sekolah dan komitmen guru terhadap penerapan nilai-nilai hidup Islami di SMK Muhammadiyah Kabupaten Tegal.

Populasi dalam penelitian ini adalah 6 Kepala Sekolah, 160 Guru, dan $\quad 1.831$ siswa SMK Muhammadiyah Kabupaten Tegal. Penentuan sampel dilakukan dengan menggunakan Proportionate Stratified Random Sampling. Adapun sampel dalam penelitian ini terdiri dari 6 orang Kepala Sekolah, 101 guru, dan 180 siswa SMK Muhammadiyah Kabupaten Tegal. Sampel guru sejumlah 101 ditentukan berdasarkan tabel penentuan sampel dari Isaac dan Michael, dengan tingkat kesalahan $10 \%$.

Pengumpulan data dilakukan secara berurutan, baik data kuantitatif maupun data kualitatif. Teknik Pengumpulan data yang digunakan dalam penelitian ini meliputi: kuesioner, wawancara, observasi, dan dokumentasi. Analisa data yang digunakan dalam penelitian ini terdiri atas tiga bagian, yaitu: (1) Analisis data kuantitatif; (2) Analisis data Kualitatif; dan (3) Analisis data kuantitatif dan kualitatif.

\section{HASIL PENELITIAN DAN PEMBAHASAN}

Distribusi Frekuensi

Distribusi frekuensi variabel penelitian diperoleh melalui angket tertutup dari sejumlah item pertanyaan dan jumlah responden sesuai dengan sampel masing-masing variabel penelitian.

Tabel 1

\section{Distribusi Frekuensi Variabel}

\begin{tabular}{|c|c|c|c|c|}
\hline No & Variabel & Kategori & Frekuensi & $\begin{array}{l}\text { Prese } \\
\text { ntase }\end{array}$ \\
\hline \multirow[t]{3}{*}{1} & \multirow{3}{*}{$\begin{array}{l}\text { Kepemi } \\
\text { mpinan } \\
\text { Kepala } \\
\text { Sekolah }\end{array}$} & Tinggi & 63 & 62,4 \\
\hline & & Sedang & 29 & 28,7 \\
\hline & & Rendah & 9 & 8,9 \\
\hline \multicolumn{2}{|r|}{ Jumlah } & & 101 & 100,0 \\
\hline \multirow[t]{3}{*}{2} & \multirow{3}{*}{$\begin{array}{l}\text { Komitme } \\
\text { n Guru }\end{array}$} & Tinggi & 64 & 63,4 \\
\hline & & Sedang & 18 & 17,8 \\
\hline & & Rendah & 19 & 18,8 \\
\hline \multicolumn{2}{|r|}{ Jumlah } & & 101 & 100,0 \\
\hline \multirow[t]{3}{*}{3} & \multirow{3}{*}{$\begin{array}{l}\text { Penerapa } \\
\mathrm{n} \text { Nilai- } \\
\text { Nilai } \\
\text { Hidup } \\
\text { Islami di } \\
\text { Sekolah }\end{array}$} & Tinggi & 117 & 65,0 \\
\hline & & Sedang & 33 & 18,3 \\
\hline & & Rendah & 30 & 16,7 \\
\hline \multicolumn{2}{|c|}{ Jumlah } & & 180 & 100,0 \\
\hline
\end{tabular}




\section{Uji Normalitas}

Uji normalitas dihitung untuk mengetahui dalam suatu model, variabel dependen dan independen atau keduanya mempunyai distribusi normal atau tidak. Dalam penelitian ini menggunakan Uji One-Sample Kolmogorov-Smirnov Test, pengambilan keputusan adalah dengan melihat angka probabilitas signifikansinya. Apabila probabilitas $>0,05$ maka data terdistribusi normal. Hasil pengujian normalitas data dapat dilihat pada tabel berikut.

Tabel 2

\section{Uji Normalitas}

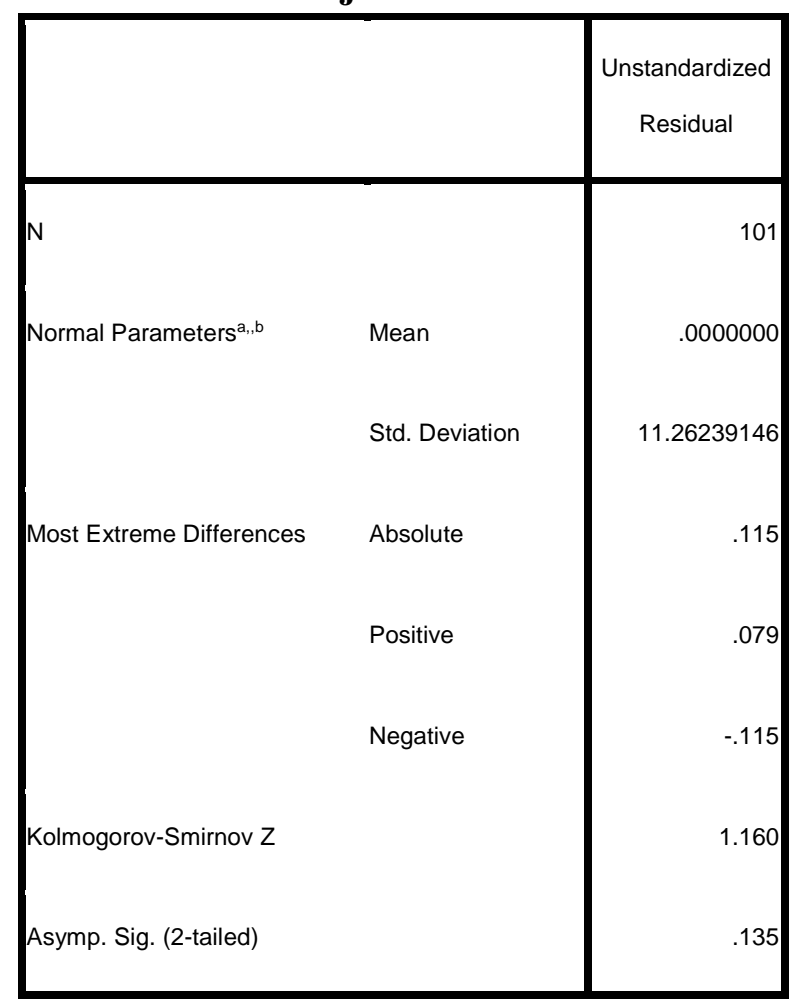

Hasil uji One Sampel Kolmogorov Smirnov menunjukkan nilai probabilitas ( $\mathrm{p}$ - value) sebesar 0,135 lebih besar dari $0,05(0,135>0,05)$.
Artinya dalam model regresi, variabel residual terdistribusi normal.

\section{Analisis Regresi Linier Sederhana}

1. Pengaruh Kepemimpinan Kepala Sekolah terhadap Penerapan NilaiNilai Islami Di Sekolah

Tabel 3

Pengaruh Kepemimpinan Kepala

Sekolah terhadap Penerapan NilaiNilai Islami Di Sekolah

\begin{tabular}{|c|r|r|r|r|r|}
\hline & \multicolumn{2}{|c|}{$\begin{array}{c}\text { Unstandardized } \\
\text { Coefficients }\end{array}$} & $\begin{array}{c}\text { Standardized } \\
\text { Coefficients }\end{array}$ & & \\
\cline { 2 - 5 } Model & B & $\begin{array}{c}\text { Std. } \\
\text { Error }\end{array}$ & Beta & $\mathrm{t}$ & Sig. \\
\hline $1 \quad \begin{array}{c}\text { (Const } \\
\text { ant) }\end{array}$ & 74.249 & 6.844 & & 10.849 & .000 \\
$\begin{array}{c}\text { kepemi } \\
\text { mpinan } \\
\text { kepala } \\
\text { sekola } \\
\text { h }\end{array}$ & .226 & .098 & .225 & 2.298 & .024 \\
& & & & & \\
\hline
\end{tabular}

Tabel di atas menunjukkan bahwa variabel kepemimpinan kepala sekolah mempunyai nilai koefisien regresi sebesar 0,226. Hal ini menunjukkan bahwa apabila kepemimpinan di sekolah semakin baik maka penerapan nilai-nilai Islami di sekolah juga akan semakin tinggi. Tabel di atas juga menunjukkan nilai sig sebesar $0,024<0,05$. Artinya kepemimpinan kepala sekolah berpengaruh signifikan terhadap penerapan nilai-nilai Islami di sekolah. 
2. Pengaruh Komitmen Guru terhadap Penerapan Nilai-Nilai Islami di Sekolah.

\section{Tabel 4}

Pengaruh Komimen Guru terhadap

Penerapan Nilai-Nilai Islami Di

Sekolah

\begin{tabular}{|c|c|c|c|c|c|c|}
\hline \multirow[b]{2}{*}{ Model } & & \multicolumn{2}{|c|}{$\begin{array}{c}\text { Unstandardized } \\
\text { Coefficients }\end{array}$} & \multirow{2}{*}{$\begin{array}{c}\begin{array}{c}\text { Standardized } \\
\text { Coefficients }\end{array} \\
\text { Beta }\end{array}$} & \multirow[b]{2}{*}{$t$} & \\
\hline & & $B$ & $\begin{array}{l}\text { Std. } \\
\text { Error }\end{array}$ & & & Sig. \\
\hline 1 & $\begin{array}{l}\text { (Consta } \\
\mathrm{nt})\end{array}$ & 42.939 & 6.210 & & 6.914 & .000 \\
\hline & $\begin{array}{l}\text { komitme } \\
\text { n guru }\end{array}$ & .309 & .119 & .252 & 2.592 & .011 \\
\hline
\end{tabular}

Tabel di atas menunjukkan bahwa variabel komitmen guru mempunyai nilai koefisien regresi sebesar 0,309. Hal ini menunjukkan bahwa apabila komitmen guru tinggi maka penerapan nilai-nilai Islami di sekolah juga akan semakin tinggi. Tabel di atas juga menunjukkan nilai sig sebesar $0,011<0,05$. Artinya komimen guru berpengaruh signifikan terhadap penerapan nilai-nilai Islami di sekolah.

\section{Analisis Regresi Linier Berganda}

Pengujian ini digunakan untuk mengetahui pengaruh variabel independen terhadap variabel dependen. Dalam hal ini pengaruh kepemimpinan kepala sekolah dan komitmen guru terhadap penerapan nilai-nilai Islami di sekolah. Hasil pengujian regresi linier berganda adalah sebagai berikut.

\section{Tabel 5}

Interpretasi Analisis Regresi Linier Berganda

\begin{tabular}{|l|c|}
\hline \multicolumn{1}{|c|}{ Variabel } & Koefisien Beta \\
\hline Konstanta & 58,610 \\
\hline $\begin{array}{l}\text { Kepemimpinan } \\
\text { kepala sekolah }\end{array}$ & 0,240 \\
\hline Komitmen guru & 0,325 \\
\hline
\end{tabular}

Dari tabel 5 di atas dapat disusun persamaan regresi sebagai berikut: $\mathrm{Y}=58,610+0,240 \mathrm{X} 1+0,325 \mathrm{X} 2$

Persamaan regresi di atas dapat diinterpretasikan sebagai berikut:

1. Konstanta $=58,610$

Konstanta sebesar 58,610 menunjukkan bahwa apabila kepemimpinan kepala sekolah dan komitmen guru tidak ada maka penerapan nilai-nilai kehidupan Islami di sekolah akan tetap sebesar 58,610.

2. Koefisien regresi $X 1=0,240$

Koefisien regresi sebesar 0,240 menunjukkan bahwa terdapat pengaruh yang searah antara kepemimpinan kepala sekolah dengan penerapan nilai-nilai hidup Islami di sekolah. Artinya apabila kepemimpinan kepala sekolah semakin baik, maka penerapan 
nilai-nilai hidup Islami di sekolah juga akan semakin tinggi.

3. Koefisien regresi $\mathrm{X} 2=0,325$

Koefisien regresi sebesar 0,325 menunjukkan bahwa terdapat pengaruh yang searah antara komitmen guru dengan penerapan nilai-nilai hidup Islami di sekolah. Artinya apabila komitmen guru semakin baik, maka penerapan nilai-nilai hidup Islami di sekolah juga akan baik.

\section{Uji F}

Pengujian ini dilakukan untuk mengetahui pengaruh secara simultan kepemimpinan kepala sekolah dan komitmen guru terhadap penerapan nilai-nilai hidup Islami di sekolah. Hasil pengujiannya adalah sebagai berikut.

\section{Tabel 6}

Hasil Uji F

\begin{tabular}{|l|c|}
\hline df 1 & 2 \\
\hline df 2 & 98 \\
\hline Nilai F hitung & 6,724 \\
\hline Nilai F tabel & 3,81 \\
\hline Probabilitas F & 0,002 \\
\hline
\end{tabular}

Berdasarkan table 6 di atas diperoleh nilai $\mathrm{F}$ hitung sebesar 6,724 lebih besar dari $\mathrm{F}$ tabel sebesar 3,81 $(6,724>3,81)$ atau probabilitas $<0,05$ $(0,002<0,05)$, artinya secara simultan kepemimpinan kepala sekolah dan komitmen guru berpengaruh signifikan terhadap penerapan nilainilai hidup Islami di sekolah. Dengan demikian hipotesis diterima.

\section{Uji t}

Pengujian ini dilakukan untuk mengetahui pengaruh secara parsial kepemimpinan kepala sekolah dan komitmen guru terhadap penerapan nilai-nilai hidup Islami di sekolah. Hasil pengujiannya adalah sebagai berikut.

Tabel 7

Hasil Uji $t$

\begin{tabular}{|l|c|c|c|}
\hline \multicolumn{1}{|c|}{ Variabel } & t hitung & t tabel & Probabilitas t \\
\hline $\begin{array}{l}\text { Kepemimpi } \\
\text { nan kepala } \\
\text { sekolah }\end{array}$ & 2,523 & 2,144 & 0,013 \\
\hline $\begin{array}{l}\text { Komitmen } \\
\text { guru }\end{array}$ & 2,794 & 2,144 & 0,006 \\
\hline
\end{tabular}

Tabel 7 di atas menunjukkan bahwa variabel kepemimpinan kepala sekolah mempunyai $\mathrm{t}$ hitung sebesar 2,523 lebih besar dari t tabel sebesar 2,144 atau probabilitas < 0,05 $(0,013$ $<\quad 0,05)$. Artinya variabel kepemimpinan kepala sekolah berpengaruh signifikan terhadap penerapan nilai-nilai hidup Islami di sekolah. Dengan demikian hipotesis diterima.

Variabel komitmen guru mempunyai $\mathrm{t}$ hitung sebesar 2,794 lebih besar dari t tabel sebesar 2,144 atau probabilitas $<0,05 \quad(0,006<$ $0,05)$. Artinya variabel komitmen guru 
berpengaruh signifikan terhadap penerapan nilai-nilai hidup Islami di sekolah. Dengan demikian hipotesis diterima.

\section{Uji Koefisien Determinasi}

Pengujian ini dilakukan untuk mengetahui seberapa besar pengaruh kepemimpinan kepala sekolah dan komitmen guru terhadap penerapan nilai-nilai hidup Islami di sekolah. Hasil pengujiannya adalah sebagai berikut.

\section{Tabel 8}

\section{Hasil Uji Koefisien Determinasi}

\begin{tabular}{|c|r|r|}
\hline R & R Square & Adjusted R Square \\
\hline 0,347 & 0,121 & 0,103 \\
\hline
\end{tabular}

Tabel 8 di atas menunjukan nilai korelasi (R) sebesar 0,347 dan nilai $R$ square sebesar 0,121. Hal ini berarti besarnya pengaruh variabel kepemimpinan kepala sekolah dan komitmen guru terhadap penerapan nilai-nilai hidup Islami di sekolah adalah $12,1 \%$.

\section{PEMBAHASAN}

Berdasarkan hasil analisis distribusi frekuensi menunjukkan bahwa kepemimpinan kepala sekolah di SMK Muhammadiyah Kabupaten Tegal termasuk dalam kategori baik, yaitu sebesar 62,4\%. Hal ini mengindikasikan bahwa sebagian besar kepala sekolah sudah menjalankan tugas pokok dan fungsinya dengan baik. kepala sekolah mempunyai kemampuan dalam bidang pendidikan, personal, relasional, intelektual, dan organisasional. Dalam bidang kemampuan pendidikan, kepala sekolah sudah berusaha untuk membangkitkan gairah belajar dan meyakini bahwa setiap anak mempunyai potensi masing-masing serta menyadari aspek-aspek penting yang dibutuhkan oleh peserta didik. Dalam bidang kemampuan personal, kepala sekolah sudah memiliki integritas dan komitmen tinggi yang ditunjukkan dengan berperilaku yang sesuai dengan etika dan moralitas serta profesionalitas. Selain itu, kepala sekolah juga menunjukkan sikap yang bertanggung jawab terhadap semua tindakan yang dilakukannya. Dalam bidang kemampuan relasional, kepala sekolah sudah menghargai pendapat orang lain dan mampu mempengaruhi orang lain sehingga mampu menjaga hubungan yang saling ketergantungan satu sama lain.

Dalam bidang kemampuan intelektual, kepala sekolah sudah mampu memahami agenda strategis dan perubahan. Selain itu, kepala sekolah juga sudah menggunakan pertimbangan asumsi dan inovasi agar tercipta proses pembelajaran yang berkualitas. Dalam bidang kemampuan organisasional, kepala sekolah sudah menjalankan proses dan struktur sekolah secara efektif dan efisien serta mengelola sumber daya untuk membangun kapasitas sekolah yang baik. 
Komitmen guru di SMK Muhammadiyah Kabupaten Tegal termasuk dalam kategori tinggi yaitu sebesar 63,4\%. Hal ini mengindikasikan bahwa sebagian besar guru sudah menetapkan dan memberikan kesetiaan terhadap profesionalitasnya sebagai guru. Komitmen guru yang tinggi ini tercermin pada komitmen afektif, komitmen berkelanjutan dan komitmen normative. Dalam komitmen afektif, dapat dilihat pada penerimaan guru terhadap nilai dan tujuan sekolah serta merasa bangga menjadi bagian dari warga sekolah. Dalam komitmen berkelanjutan ini, ditunjukkan oleh adanya keinginan guru untuk tetap bertahan dalam organisasi sekolah dan merasa senang ikut terlibat aktif dalam menyelesaikan tugas-tugas sekolah. Pada komitmen normative, ditunjukkan oleh adanya kesadaran dari guru untuk melaksanakan nilainilai dan tujuan sekolah serta menunjukkan kesetiaan pada sekolah. Perilaku-perilaku yang ditunjukkan guru tersebut menunjukkan bahwa guru sudah menunjukkan aspek komitmen dan tanggung jawab terhadap profesinya.

Hasil analisis distribusi frekuensi juga menunjukkan bahwa penerapan nilai-nilai hidup Islami di SMK Muhammadiyah Kabupaten Tegal termasuk dalam kategori baik, yaitu sebesar $65,0 \%$. Kondisi ini menunjukkan bahwa sebagian besar siswa SMK Muhammadiyah
Kabupaten Tegal sudah menerapkan nilai-nilai hidup Islami dalam kehidupan sehari-hari. Hal ini tercermin dalam aqidah, akhlak, ibadah dan muamalah yang dilakukan siswa. Dalam hal aqidah, siswa sudah mempunyai prinsip hidup dan keimanan yang benar, ikhlas dan penuh ketundukan kepada Allah SWT serta menjadikan iman dan tauhid sebagai sumber dari semua kegiatan. Dalam hal akhlaq, siswa sudah menunjukkan perilaku yang ushwah hasanah, mulia dan menjauhkan diri dari akhlaq yang tercela. Dalam hal ibadah, siswa sudah berusaha untuk membentuk pribadi yang muttaqin dan menjalankan ibadah mahdhah dengan sebaik-baiknya sesuai tuntunan Rasulullah. Dalam hal muamalah, siswa sudah berusaha untuk menyikapi kehidupan secara aktif dan positif dan mempunyai semangat kerja yang Islami. Perilaku-perilaku tersebut menunjukkan bahwa siswa sudah memilih perilaku atau cara hidup menurut Islami.

Berdasarkan analisis regresi diperoleh hasil bahwa variabel kepemimpinan kepala sekolah berpengaruh signifikan terhadap penerapan nilai-nilai hidup Islami di SMK Muhammadiyah Kabupaten Tegal. Ditunjukkan oleh nilai probabilitas sebesar $0,024<0,05$. Nilai koefisien regresi yang positif menunjukkan bahwa terdapat pengaruh yang searah antara kepemimpinan kepala sekolah dengan penerapan nilai-nilai hidup Islami di 
sekolah. Artinya, semakin baik kepemimpinan kepala sekolah maka penerapan nilai-nilai hidup Islami di sekolah juga akan semakin baik. Hasil analisis regresi juga menunjukkan bahwa komitmen guru berpengaruh signifikan terhadap penerapan nilainilai Islami di sekolah. Ditunjukkan oleh nilai probabilitas sebesar $0,011<$ 0,05 . Hal ini mengindikasikan bahwa komitmen guru juga berperan penting dalam penerapan nilai-nilai Islami di sekolah.

\section{KESIMPULAN DAN SARAN \\ Kesimpulan}

Beberapa

kesimpulan

berdasarkan hasil penelitian dan hasil analisis adalah sebagai berikut:

1. Kepemimpinan Kepala Sekolah berpengaruh signifikan terhadap penerapan nilai-nilai hidup Islami di SMK Muhammadiyah Kabupaten Tegal, ditunjukkan oleh nilai t hitung lebih besar dari t tabel $(2,523>2,144)$ atau nilai sig sebesar $0,013<0,05(\mathrm{p}<$ 0,05). Variabel kepemimpinan kepala sekolah mempunyai nilai koefisien regresi sebesar 0,226. Hal ini menunjukkan bahwa apabila kepemimpinan di sekolah semakin baik maka penerapan nilai-nilai hidup Islami di sekolah juga akan semakin tinggi. Sebaliknya, apabila kepemimpinan di sekolah semakin tidak baik maka penerapan nilainilai hidup Islami di sekolah juga akan semakin rendah.
2. Komitmen guru berpengaruh signifikan terhadap penerapan nilai-nilai hidup Islami di SMK Muhammadiyah Kabupaten Tegal, ditunjukkan oleh $\mathrm{t}$ hitung lebih besar dari t tabel $(2,794>2,144)$ atau nilai sig sebesar $0,006<0,05$ $(\mathrm{p}<0,05)$. Nilai koefisien regresi komitmen guru sebesar 0,309, ini menunjukkan bahwa apabila komitmen guru tinggi maka penerapan nilai-nilai hidup Islami di sekolah juga akan semakin tinggi. Sebaliknya, apabila komitmen guru rendah maka penerapan nilai-nilai hidup Islami di sekolah juga akan semakin rendah.

3. Secara simultan kepemimpinan Kepala Sekolah dan komitmen guru berpengaruh signifikan terhadap penerapan nilai-nilai hidup Islami di SMK Muhammadiyah Kabupaten Tegal, ditunjukkan oleh $\mathrm{F}$ hitung lebih besar dari $\mathrm{F}$ tabel $(6,724>3,81)$ atau nilai sig sebesar $0,002<0,05$ $(\mathrm{p}<0,05)$. Nilai $\mathrm{R}$ square sebesar 0,121 , Hal ini berarti besarnya pengaruh variabel kepemimpinan kepala sekolah dan komitmen guru terhadap penerapan nilainilai hidup Islami di sekolah adalah $12,1 \%$.

\section{Saran}

Berdasarkan hasil penelitian yang diperoleh, beberapa saran yang dapat diajukan: 
1. Bagi Pimpinan Daerah Muhammadiyah Kabupaten Tegal, diharapkan dapat terus melakukan pembinaan kepada kepala sekolah dan guru-guru tentang penerapan nilai-nilai hidup Islami di sekolah, baik dengan kegiatan yang formal maupun kegiatan informal.

2. Bagi sekolah, diharapkan pihak sekolah terus mendorong kegiatan siswa yang berkaitan dengan keagamaan. Selain itu, membuat peraturan yang mempunyai sanksi tegas sehingga siswa menjadi jera.

3. Bagi penelitian selanjutnya, diharapkan dapat menambah variabel lain yang diduga mempengaruhi penerapan nilainilai hidup Islami di sekolah, misalnya peran orang tua dan lain sebagainya.

\section{DAFTAR PUSTAKA}

Ali, Akbar. 2012. Internasional Journal of Learning and Development. Leadership and Its Influence in Organizations. Faculty of Management Information Systems National University of Sciences and Technology. Pakistan.

Firdaus, $\quad$ Raudlotul. 2013. International Journal of Educational and Research. Islamic Education: The Philoshophy, Aim, and main Features. International Islamic University Malaysia. Kuala Lumpur. Vol 1.

Gunawan, Imam., Noor Benty, Djum Djum. 2017. Manajemen
Pendidikan Suatu Pengantar Praktis. Alfabeta. Bandung.

Harmaini., dkk. 2016. Psikologi Kelompok Integrasi Psikologi dan Islami. Raja Grafindo Persada. Jakarta.

Hosnan, M. 2016. Etika Profesi Pendidik. Ghalia Indonesia. Bogor.

Majelis Pendidikan Dasar dan Menengah. 2017. Data Jumlah Guru Karyawan dan Siswa. Pimpinan Daerah Muhmmadiyah Kabupaten Tegal.

Marshall, Alwyn, Ian. 2015. Principal LeadershipStyle and Teacher Commitment among a Sample of Secondary School Teachers in Barbados. School of Education, The University of the West Indies. Barbados.

Mulyana, Rohmat. 2013. Model Pembelajaran Nilai Melalui Pendidikan Agama Islami. Saadah Pustaka Mandiri. Jakarta.

Mulyasa, E. 2013. Menjadi Kepala Sekolah Profesional. Remaja Rosda Karya. Bandung.

Natile, J Allen., John. P Meyer. 1990. Journal of Occupational Psychology. The Measurement and Antecendents of Affective, Continuance and Normative Commitment to The Organization. The British Psychological Society. 
Pimpinan Pusat Muhammadiyah. 2002. Pedoman Hidup Islami Warga Muhammadiyah. Suara Muhammadiyah. Yogyakarta.

Priansa, Juni, Donni., Somad, Rismi. 2014. Manajemen Supervisi \& Kepemimpinan Kepala Sekolah. Alfabeta. Bandung.

Robbins. 2006. Perilaku Organisasi: Konsep Kontroversi, Aplikasi. Terj. Molan, Benyamin. Prenhelindo. Jakarta.

Sahertian, Piet., 1994. Profil Pendidik Profesional. Andi Offset. Yogyakarta.

Salam, Burhanudin., 1995. Pengantar Pedagogik (Dasar-Dasar Ilmu Mendidik). Rineka Cipta. Jakarta.

Sanusi, Achmad 2017. Sistem Nilai: Alternatif Wajah-wajah Pendidikan. Nuansa. Bandung.

Soekanto, Soerjono., Sulistyowati, Budi., 2015. Sosiologi Suatu Pengantar. Raja Grafindo Persada. Jakarta.

Sugiyono. 2015. Metode Penelitian Kuantitatif Kualitatif dan R \& D. Alfabeta. Bandung.

Supriyatno, Triyo., W mamat, Hasmah. 2014. Internasional Journal of Academic Research. Akhlaq Leadership and Islamic School in Malang Indonesia. Universitas Islami Negeri maulana malik Ibrahim Malang (Indonesia), Universitas Malaya (UM Malaysia). Vol. 6. No. 1.
Undang-Undang No. 20 tahun 2003.

Usman, Moch. Uzer. 2016. Menjadi Guru Profesional. Remaja Rosda Karya. Bandung.

Wahjosumidjo.

2013.

Kepemimpinan Kepala

Sekolah tinjauan teoritik dan permasalahannya. Cetakan ke-9. Raja Grafindo Persada. Jakarta.

Woolfolk, Anita., 2009. Educational Psychology. Edisi Kesupuluh. Pustaka Pelajar. Yogyakarta. 